\title{
Influence of Shopping Experience on Shopping/Convenience Store Selection
}

\author{
Malik Mubashir Hussain ${ }^{1} \&$ Danish Ahmed Siddiqui ${ }^{1}$ \\ ${ }^{1}$ Karachi University Business School, University of Karachi, Pakistan \\ Correspondence: Malik Mubashir Hussain, Research Scholar, Karachi University Business School, University of \\ Karachi, Pakistan.
}

Received: March 19, 2019

Accepted: April 10, 2019

Online Published: April 14, 2019

doi:10.5430/ijba.v10n3p74

URL: https://doi.org/10.5430/ijba.v10n3p74

\begin{abstract}
In this paper the influence of shopping experience on a specific shopping store selection has been investigated. Four dimensions of shopping experience namely Accessibility, Atmosphere, Environment and Service Personnel were proposed, and a 15-item measure is developed to measure 304 consumer perceptions of the shopping experience across different regions of Pakistan using Structural Equation Modelling. Findings indicate that shopping experience enjoyment has a significant positive influence upon customers' selection of shopping destinations. Furthermore, the study highlights different aspects under which these preferences could be altered such as under gender Influence, economic factors, legal boundaries; these preferences seem to be affected up to a considerable amount and the impact of such factors could not be overlooked.
\end{abstract}

Keywords: shopping experience, shopping store selection, accessibility, atmosphere, environment, shopping personnel

\section{Introduction}

\subsection{Background of the Study}

It is a mutual thinking that shopping experience starts when a shopper enters a store or an e-commerce website and stops when this same shopper leaves with its purchases. One of the key decisions faced by shopper is where to shop in terms of shopping location and store choice (Sit, Merrilees and Birch, 2003). As a result, retailer concern with patronage and re-patronage is now an important topic of marketing research (Machleit, Meyer and Eroglu, 2005). The store image has greater influence on shopper buying decision. Prior research concluded that store image has play important role in customer investment decisions (Oppewal and Timmermans, 1997). This is important to understand that does shopping experience effect convenience store selection and what appeals consumer about specific shopping centers, followed by effective management of consumer evaluation, should lead to increase re-patronage intentions. Different shoppers have different and important choices of shopping locations. However, in this regard regional shopping centers in particular play a key role in the future of the modern economy (Finn and Louviere, 1996; Phillips and Swaffin-Smith, 2004). Since shopping has been recognized as the primary purpose for the majority of visits to town and city centers (Warnaby and Davies, 1997) containing the accurate retail offers and facilities to help the shoppers into a regional center results in increased spending, greater employment opportunities and hence local economic regeneration. Regional shopping centers represent more than a shopping mall in this instance. For the purposes of this paper, they include shopping areas with a wide range of shopping facilities within larger geographical regions, such as town or city centers. They contain a mixture of traditional high streets, commercial shopping malls and smaller shopping precincts, and incorporate features which are either privately owned (merchandise, buildings, signs) or publicly owned (roads, car parks and amenities) (Bell, 1999). Perhaps a major difference is that whilst specific retailers and shopping malls have a long history of coordinating their advertising and promotion efforts, regional shopping centers have only recently begun to market themselves in terms of image creation and maintenance (Kirkup and Rafiq, 1999; Kupke, 2004; Warnaby and Medway, 2004).

\subsection{Gap Analysis}

The previous researches were all based on the intentions of the customers store selections but not on the actual decisions that they take (Cathy Hart and Andrew M. Farrell, 2010). This research focuses more on the actual 
behaviors of the shoppers. Moreover, the earlier researchers involved the basic elements of the shopping experience and not the detailed aspects of the shopping experience for instance, it could be argued that shopping enjoyment may influence the discretionary amount that shoppers are prepared to spend in a shopping trip; it is established that increased time spent in the retail environment results in higher spending (Donovan, Rossiter, Marcoolyn and Nesdale. 1994; Wakefield and Baker, 1998). This research broadens the measuring dimensions of the shopping experience influence. Previous researches were carried out in the western regions of the globe such as the work performed by (Cathy Hart and Andrew M. Farrell, 2010; Wakefield and Baker, 1998); but this research focuses on the eastern regions, particularly Pakistan, Asia. Furthermore, it could be interesting to see how the concept of entertainment, as discussed by (Sit, Merrilees and Birch, 2003), relates to excitement, enjoyment and quality perceptions of customers, and how in turn it may influence re-patronage.

Previous researches performed by Cathy Hart and Andrew M. Farrell, (2010) have shown that store image has a significant role to play in consumers' patronage decisions; thus, it may be assumed that the image of a shopping centre may also impact on consumers' decisions of where to shop. However, while considerable work has been done on the role of store and even shopping mall image on consumer patronage, until now there is very little research examining the image of the regional shopping centre, as a more complete entity, in determining consumers' patronage decisions. This is important because understanding more about what attracts consumers to a specific shopping centre, followed by effective management of consumer evaluation, and should lead to increased re-visiting intentions.

Most of the research in this field has concentrated on shoppers' responses at the individual store or, at most, the shopping mall level; this study focuses on a relatively untouched area of research, in terms of exploring the impression or holistic image of a shopping center as a whole and the influence it can have upon customers' future shopping decisions (Bell, 1999; Warnaby and Medway, 2002). Furthermore, the literature also implies that shopping enjoyment may be a function of gender. For example (Otnes and McGrath, 2001) distinguish gender variances in shopping behavior, involvement in the shopping process and attitudes towards shopping as a social activity. This is consistent with the view that women behave differently to men and often display differing approaches to socialization.

\subsection{Problem Statement}

This research seeks to identify the broad factors that contribute to consumer image perceptions of shopping centers and their related enjoyment of the shopping experience. Secondly, the research aims to determine the impact that enjoyment of shopping on specific shopping centers has upon customers re-patronage intentions. Considering this all, the article examines how the shopping experience influences convenience store selection, as well as the appeal of the shopping center itself can impact shopper behavioral responses and whether they intend to re-patronize that shopping center

\subsection{Research Questions}

For this, the article focuses on four major aspects of the shopping experience i.e. Accessibility, Atmosphere, Environment and Personnel. And under all these four dimensions further sub-elements are also provided and by the end, following questions are broadly answered with the help of the responses and data collected;

Q1. Does 'Accessibility' of the store have significant influence on Shopping/convenience store selection or not?

Q2. Does 'Atmosphere' of the store have significant influence on Shopping/convenience store selection or not?

Q3. Does 'Environment' of the store have a significant influence on Shopping/convenience store selection or not?

Q4. Do 'Personnel' of the store have a significant influence on Shopping/convenience store selection or not?

\subsection{Limitations}

Some limitations of the research are as follows. At first, only some limited variables were measured in this research. There could be other factors that may be considered in the domain of shopping experience. The quantity and quality of the enjoyment offered in a shopping destination could be one of the possibilities. For instance, some of the shopping destinations offer added entertainment during special seasons such as EID, Ramadan, Independence Day, etc. Therefore, enjoyment of shopping activity could also be affected by seasonal occasions.

Second, this work is cross-sectional that measures the enjoyment of respondent's shopping experience and aims to choose a shopping centre at a specific time. Therefore, deductions related to fundamental order among the variables of interest could not be generated, and while interpreting the conclusions, certain care should be taken into consideration. 
Third, even though this research has defined many variables that are related to shopping experience enjoyment, it is still possible that these variables could be more influential than others when it comes to enjoyment levels and re-patronage intentions. Future research could be conducted to investigate the factors used by customers to evaluate their shopping enjoyment and a specific regional store. Moreover, it would also be effective to identify and investigate other consumer segments such as shopper's age, education, income, etc.

\section{Literature Review}

\subsection{Store Selection}

Since the early conceptualization of store image by Martineau (1958), various researchers have sought to decompose image into a set of dimensions that are most valued by consumers and thus may be controlled and measured. The quality of the shopping experience is generally thought to have a positive effect on customers' behavioral intentions (Tai and Fung, 1997; Wakefield and Baker, 1998).

The image of a shopping location has been described as a multidimensional concept consisting of features which are broadly summarized into two categories: firstly tangible or functional attributes which relate to its physical features; and secondly the more intangible attributes which represent its atmospheric qualities (McGoldrick, 2000). Thus, according to Lindquist (1974) the nine different dimensions contributed to consumers' perceptions of store image; namely merchandise, service, clientele, physical facilities, convenience, promotion, store atmosphere, institutional factors and post-transactional satisfaction.

While many of these aspects of store image are also applicable to the broader regional shopping center, the regional center as a whole also contains public spaces which are beyond the scope of individual retailers to directly manage or influence, such as architectural design, street layouts, tenant mix, parking, refreshment and toilet facilities (Bell, 1999; Oppewal and Timmermans, 1999). These studies (ibid) have shown that such aspects of retail area will also influence customer perceptions and hence patronage intentions.

It is established that the concept of image is intrinsically linked to retail patronage (e.g. Darden and Babin, 1994) and store loyalty (Mazursky and Jacoby, 1986).

A strong image of a shopping location creates competitive advantage (Sit, Merrilees and Birch, 2003), being associated with greater willingness to purchase, longer time spent shopping and higher sales turnover; in effect more positive patronage behaviour (Bitner, 1992; Dennis, Newman and Marsland, 2005; Oppewal and Timmermans, 1997).

Positive image has been shown to create higher levels of pleasurable feelings in customers and reflects their enjoyment of spending time in the area (Bell, 1999). Some attention in the retail literature has focused on the notion of excitement (Wakefield and Baker, 1998). However, whilst excitement corresponds to an emotional state that elicits high levels of pleasure and arousal, enjoyment tends to represent a less emotionally intensive evaluation, which is similar to liking. Of the two emotional states, logic would dictate that customers would find themselves in a state of enjoyment more often than a state of excitement, especially if they are regular shoppers. The longer a consumer spends in a retail environment, the more they are likely to spend (Donovan, Rossiter, Marcoolyn and Nesdale, 1994; Wakefield and Baker, 1998). Work by Donovan and Rossiter (1982) found that enjoyment of a retail experience results in more time being spent shopping and return patronage.

Enjoyment itself has been reported as a motivation for 'bricks' shopping, as opposed to shopping on the Internet [Dennis, Newman and Marsland, 2005] so the importance of the construct to modern shopping centers is clear. (Wakefield and Baker, 1998) further hypothesized that higher levels of excitement lead to greater re-patronage intentions.

\subsection{Dimensions of Store Selection}

Consequently, for the purposes of this study, we focus on those factors that are specific to the shopping center as a whole. Specifically, building on attributes of shopping centre image commonly discussed in the literature, we identify four dimensions, which we believe are related to shopping enjoyment experience. These attributes are selected for their relevance in defining a particular shopping center as a holistic entity, rather than relating to individual stores.

\section{a) Accessibility}

First accessibility linked to the convenience and logistic aspects of store location, travel, parking and pedestrian areas. This functional dimension of shopping center image has received attention in the literature, and is considered important on a number of fronts (Sit, Merrilees and Birch, 2003; Dennis, Newman and Marsland, 2005). However, 
some early research has considered travel distances in relation to shopping center patronage, Bell (1999) in particular notes that these considerations have until now failed to capture emotional responses which lead to consumers' image perceptions.

With increased car ownership, customers are prepared to travel longer distances to patronize shopping centers where the retail mix is sufficiently attractive, rather than making shopping center choices based on the nearest convenient location (Dennis, Marsland and Cockett, 2002; Whyatt, 2004). This suggests that ease of travel to and within attractive locations has an important role in shopping decision making, particularly in regard to the growth of competition from Internet shopping (Dennis, Newman and Marsland, 2005).

Sit, Merrilees and Birch (2003) separate accessibility in a shopping center into 'macro-accessibility' which refers to transport links from the home location to the shopping center, and 'micro-accessibility' which refers to parking facilities and ease of navigation between stores and other facilities within the center, arguing that paying attention to both aspects will make the shopping experience more enjoyable. This is supported by Leo and Philippe (2002) who indicate that poor directional indicators for travellers to a shopping location result in dissatisfaction and disappointment with the shopping expedition. Oppewal and Timmermans (1999) found that one of the aspects of the micro-accessibility of public space, which were favored by customers, was compactness of layout, in terms of accessing stores and space reserved for pedestrian access.

The factors that influence consumer perception of shopping accessibility related to enjoyment of shopping experience for shoppers include transport links, car parking facilities, store location (convenience for consumer) and pedestrians for ease.

b) Atmosphere

In the special case of a shopping center, atmosphere relates to perceptions of the visual appeal of the architecture and window displays, appreciation of store variety, and the comfort elements provided by cafes and restaurants, all of which are associated with positive evaluations of a shopping center and hence likelihood to re-patronize (Wakefield and Baker, 1998).

The effects of atmospherics, or physical design elements, on consumers is recognized by managers and mentioned in virtually all marketing, retailing, and organizational behavior texts (Bitner, 1992; Mazursky and Jacoby, 1986; McGoldrick and Pieros, 1998; Spies, Hesse and Loesch, 1997), and has been argued to provide an extremely effective point of competitive differentiation (Bell, 1999; Tai and Fung, 1997). However, despite this attention, little empirical work has been completed to address the effects of physical surroundings on customers' behavioral responses in regional shopping centers (Dennis, Murphy, Marsland, Cockett and Patel, 2002; Kirkup and Rafiq, 1999). Atmosphere is created by the interaction between the location's physical attributes and customers' subjective perceptions (Hackett, Foxall and Van Raaij, 1993). Therefore atmosphere is reflected in customers' reactions to the physical environment and is related to purchasing behavior (Spies, Hesse and Loesch, 1997; Smith and Burns, 1996; Tai and Fung, 1997). Within the store environment, customers are stimulated by atmospheric aspects such as music, lighting, space, colors and aromas (McGoldrick and Pieros, 1998; Wakefield and Baker, 1998). The attractiveness of storefronts and window displays, and the availability of cafes and restaurants, also contribute to atmospherics in a shopping location (Oppewal and Timmermans, 1999; Sit, Merrilees and Birch, 2003; Warnaby and Medway, 2004).

According to environmental psychologists, individuals respond to places with two general reactions: approach and avoid (Mehrabian and Russell, 1974). Approach behaviors include all positive behaviors that might be directed towards a place, such as desire to stay or explore (Bitner, 1992). A study by Donovan and Rossiter (1982) found that in retail settings perceptions of the shopping environment influenced positive approach behaviors, namely shopping enjoyment, returning, and time spent browsing. The better the atmosphere, the more positive the perceptions of the shopping center are likely to be (Bitner, 1992). The atmosphere has a positive influence upon shopping enjoyment. This leads us to propose that customers' enjoyment of the shopping experience will be reflected by their perceptions of the atmosphere of the shopping region.

c) Environment

Environment refers to consumers' responses to the most practical aspects of shopping center management. Previous research has identified these aspects to include cleanliness of the shopping center (Oppenwal and Timmermans, 1999), opening hours and security (Lehtonen and Maenpaa, 1997), which, when combined have been shown to influence patronage decisions (Sit, Merrilees and Birch, 2003).

Characteristics of the physical shopping environment also influence perceptions of that environment (Bitner, 1992), and the retail environment also influences shopping enjoyment and return behavior (Donovan and Rossiter, 1982). 
These factors are within the responsibility of managers of regional shopping centers, and include security, cleanliness of the shopping center, and opening hours which are convenient to customers (Sit, Merrilees and Birch, 2003; Whyatt, 2004).

These factors have received limited attention in the literature (Sit, Merrilees and Birch, 2003), yet are important considerations in customers' image perceptions of the shopping center, as distinct from individual stores or even shopping malls. Perceptions of high levels of crime associated with the regional area in general create negative image connotations for the shopping center within that area, which are unrelated to individual stores (Sit, Merrilees and Birch, 2003). Keeping the public space areas clean and tidy through maintenance of the streets, hallways and buildings is an important factor in customers' perceptions of the pleasantness of the shopping experience (Oppewal and Timmermans, 1999). As customers become increasingly time-pressed, and with the availability of extended shopping hours, store opening hours, which are convenient for those who cannot shop during 'normal' shopping times, are a factor in encouraging many more customers to patronize the shopping center (McGoldrick, 2002; Wakefield and Baker, 1998).

d) Service Personnel

Service personnel have an important part to play in influencing customers' shopping experience and the positive or negative impression formed by the customer (Bitner, Booms and Tetreault, 1990; McGoldrick, 2002; Parasuraman, Zeithaml and Berry, 1988). Indeed, according to Mittal and Lassar (1996, p. 105) personnel displaying interest and warmth can lead to a 'personally rewarding shopping and service experience'.

Previous work examining service encounters in retail settings has found that the attitudes and behaviors of employees can have a positive influence upon customers' emotions, satisfaction, perceptions of quality and hence purchase intentions (Babin, Babin and Boles, 1999; Baker, Parasuraman, Grewal and Voss, 2002; Dabholkar, Thorpe and Rentz, 1996; Parasuraman, Zeithaml and Berry, 1988). Similarly, it has been found that delays in service, or poor service overall, can lead to negative impressions being formed of the service received (Bitner, Booms and Tetreault, 1990).

At the level of the individual retail store, evaluations of service quality are known to be linked with re-patronage intentions, with more favorable perceptions of service quality resulting in more favorable behavioral intentions such as recommendation, preference and greater re-patronage (Darian, Tucci and Wiman, 2001; Sivadas and Baker-Prewitt, 2000). Customer service quality is variously described as consisting of friendliness, knowledge of goods sold, ability to give advice, respect and responsiveness without being 'pushy' (Darian, Tucci and Wiman, 2001; Leo and Philippe, 2002). Leo and Philippe (2002) defined that knowledgeable staff that gave good advice to perceptions of the entire shopping center, rather than an individual store. Sivadas and Baker-Prewitt (2000) consider that, unlike customer satisfaction, which represents an evaluation of an individual service encounter, 'service quality' refers to a global measure of service performance, which can be extended to the shopping center level.

On the other hand there many other factor that impacts the selection of store, such as emotional attachment and shopping enjoyment tendency which means the shopper move towards that store for which he/she is emotionally attracted or in which they enjoy the overall shopping experience.

Shopping has been recognized as a mindless activity. The systematized convenience store facilitates shoppers with entertaining facilities (Pine \& Gilmore, 1998), such as music, aroma and refreshment facilities that generates fun and enjoyment (Holbrook \& Hirschman, 1982; Wakefield \& Baker, 1998) and creates feeling of pleasure and excitement in the mind of shopper. The shopping enjoyment tendency is discussed as a particular internal stable tendency (Chavosh et al., 2011) to enjoy the overall shopping process. Shopping enjoyment tendency has been reflected as a shopper internal characteristic that makes them feel relax and refresh their mood swings (Pandey, 2016) in the enjoyable convenience store environment (Wakefield \& Baker, 1998).

Arnold and Reynolds (2003) recommend that enjoyment part of convenience store is deliberated as the most significant competitive tool, encourage shoppers to spend longer browsing time (Chavosh et al., 2011). Rook (1987) classifies that shopper with high participation likes to frequently browse convenience stores that carry particular products or goods for fun and pleasure, and involve them in impulse buying than low involvement shopper.

According (Babin \& Darden, 1996) todays shoppers visit the retail store to get relax, refresh and for positive feelings along with shopping process. Therefore, the selection of attractive and organized store is come in consideration of shoppers. For which the retailer generates a positive feeling shopping environment by nourishing shopper's emotional needs (Arnold \& Reynolds, 2003; Holbrook \& Hirschman, 1982; Wakefield \& Baker, 1998).

Shoppers usually like to visit or select that store which they are emotionally attached and that store gives them 
positive and enjoyable shopping experience (Holbrook \& Hirschman, 1982). Positive feeling and happiness of shopping process have a direct association with shopper satisfaction (Babin \& Darden, 1996). In addition to this, higher level of assignation and participation with the specific manufactured goods and service classifications obtains a great deal of fun and pleasure increase tendency of consumers to browse retail store regularly. Motivational activities (such as attractive pricing and promotion) and the product display in the retail store in also the one of the reason of selecting store for shopping.

It is hypothesized that these four dimensions will reflect a higher order latent construct, namely enjoyment of the shopping experience. We will discuss in more detail the reasoning behind the formation of the enjoyment of the shopping experience construct, based upon a brief review of the retail and shopping literature.

\subsection{Hypothesis Development}

H1: Shopping Experience has a positive influence on Shopping/convenience store selection.

This hypothesis could be further derived from the parameters of the Shopping Experience mentioned above i.e. "Accessibility", "Atmosphere", "Environment", "Personnel".

H1a: 'Accessibility' of the store has a significant influence on Shopping/convenience store selection.

H1b: 'Atmosphere' of the store has a significant influence on Shopping/convenience store selection.

H1c: 'Environment' of the store has a significant influence on Shopping/convenience store selection.

H1d: 'Personnel' of the store has a significant influence on Shopping/convenience store selection.

\section{Research Methodology}

The aim of the research was to examine the concept of Shopping Experience and its influence on Shopping/Convenience Centre selection in Pakistan's shopping regions. For this purpose, a quantitative approach was adopted, using different questionnaires submitted to respondents during face-to-face interviews and also by online means. Such methods allow for the controlled collection of large amounts of specific information from respondents [Churchill and Lacobucci, 2004].

\subsection{Sample}

During various shopping hours of the day the survey was conducted in 2018. As the primary interest area of was the Southern region of the Pakistan, people in different regional towns and cities were inquired. Interviewers were asked only to target those respondents who were resident in the area of interest. The study involved 304 respondents, mainly from different regions of Karachi. Once interviews were finished, responses from other irrelevant regions were removed.

Table 1. Sample statistics

\begin{tabular}{llllll}
\hline GENDER & Frequency & Percentage & Employment Status & Frequency & Percentage \\
\hline Male & 150 & 49.3 & Formal & 174 & 57.2 \\
\hline Female & 154 & 50.7 & Informal & 130 & 42.8 \\
\hline Total & 304 & 100 & Total & 304 & 100 \\
\hline AGE & Frequency & Percentage & EDUCATION & Frequency & Percentage \\
\hline $18-29$ & 232 & 76.3 & College & 26 & 8.6 \\
\hline $30-45$ & 58 & 19.1 & University & 126 & 41.4 \\
\hline Above 46 & 14 & 4.6 & Graduate & 152 & 50 \\
\hline Total & 304 & 100 & Total & 304 & 100 \\
\hline Marital Status & Frequency & Percentage & & & \\
\hline Single & 224 & 73.7 & & & \\
\hline Married & 80 & 26.3 & & & \\
\hline Total & 304 & 100 & & & \\
\hline
\end{tabular}


A random stratified sample was used. The sample consisted 154 females and 150 males. The major age group was of (18-29 years) with 232 responses while the remaining responses came from other age groups i.e. 58 from (30-45 years) and 14 from (Above 46 years). 58\% respondents were employed and $74 \%$ were still bachelors (Table 1).

\subsection{Measurement}

Respondents were requested to name the place where they shopped most and to give their insights about their current shopping destination. In order to generate the scale to measure shopping experience, questionnaire items were adapted from previous work by Wakefield and Baker [2007], Oppewal and Timmermans [2008] and Sit, Merrilees and Birch [2011].

As opposed to describing characteristics of separate stores items were selected for relevance to the shopping region as a whole. For example, dimensions of macro-accessibility, micro-accessibility, personal service, food stops, and security were selected from Sit, Merrilees and Birchs' [2011] work for the scale, while items that were more relevant to individual stores, like product range music and color scheme, were omitted. Items to evaluate customer perceptions of window displays, public spaces, pedestrianized areas and maintenance (or cleanliness) were also employed from Oppewal and Timmermans' [2008] construct. Finally, in order to evaluate architecture and design factors, store variety, items appearing in the work on shopping malls of Wakefield and Baker [2007] were adapted, again omitting items such as aroma and temperature, which refer to individual stores.

Therefore, to measure all the four dimensions of shopping experience, 14 items were produced from the literature. Overall, the construct was designed to highlight the amount of pleasure and excitement derived from a shopping centre experience, it comprised of the following four dimensions;

\section{1- 'Accessibility' of Shopping Centre.}

2- 'Atmosphere' of Shopping Centre.

3- Attitudes towards 'Environment'.

4- Attitudes towards Shopping Centre's 'Personnel'.

The endogenous variable was 'Shopping/Convenience Centre selection'. This product was measured by a single item: "Rate your current convenience/shopping Centre's overall shopping experience". Respondents indicated the extent to which they agreed with each questionnaire item using a 1-5 item scale ranging from 1 (very bad experience) to 5 (very good experience). In addition to the scale questions, respondents also supplied demographic data, including age, gender, employment and marital status.

\subsection{Scale Properties}

Initially, all the 15 items containing the shopping enjoyment and location attractiveness scale had their variability measured. The 15 items showed acceptable means and standard deviations specified the scale range from 1 to 5 (the individual item means ranged from ' 2.7 ' to ' 4.3 '; while standard deviations ranged from ' 0.83 ' to ' 1.29 ') (See Table 2).

An exploratory factor analysis was carried out for all the 15 items to identify the poorly performing items, and confirmatory analysis for additional scale purification. All structural equation models were assessed using 'AMOS' utilizing the maximum likelihood procedure and the covariance matrix as input. The confirmatory factor analysis results for all the 15-item measurement model are shown in Table 3.

The responses obtained from the research questionnaire show that nearly all the factors of shopping experience are important for the shoppers;

- Attractive Buildings and Cafés have a fair influence on customer's store selection.

- Window Displays, Walking Path, Travelling to Shop, Store Variety, Shopping hours, Parking and Shopping Experience influence the store selection strongly.

- Location, Service, Cleanliness, Staff Attitude and Safety has a very strong influence on customer store selection. 
Table 2. Descriptive statistics

\begin{tabular}{|c|c|c|c|c|c|c|c|}
\hline & $\mathrm{N}$ & Range & Minimum & Maximum & Mean & Std. Deviation & Variance \\
\hline Attractive Buildings & 304 & 4.00 & 1.00 & 5.00 & 2.6513 & 1.16755 & 1.363 \\
\hline Cafes & 304 & 4.00 & 1.00 & 5.00 & 2.8947 & 1.16130 & 1.349 \\
\hline Windows Displays & 304 & 4.00 & 1.00 & 5.00 & 3.3421 & 1.13803 & 1.295 \\
\hline Walking Path & 304 & 4.00 & 1.00 & 5.00 & 3.3618 & .97188 & .945 \\
\hline Travelling to Shop & 304 & 3.00 & 2.00 & 5.00 & 3.4408 & .98660 & .973 \\
\hline Store Variety & 304 & 4.00 & 1.00 & 5.00 & 3.6974 & 1.00191 & 1.004 \\
\hline Shopping Hours & 304 & 4.00 & 1.00 & 5.00 & 3.7039 & .95329 & .909 \\
\hline Parking & 304 & 4.00 & 1.00 & 5.00 & 3.7171 & 1.19635 & 1.431 \\
\hline Shopping Atmosphere & 304 & 3.00 & 2.00 & 5.00 & 3.8289 & .90307 & .816 \\
\hline Store Experience & 304 & 2.00 & 3.00 & 5.00 & 4.0230 & .68660 & .471 \\
\hline Location & 304 & 4.00 & 1.00 & 5.00 & 4.0789 & .89388 & .799 \\
\hline Service & 304 & 3.00 & 2.00 & 5.00 & 4.1316 & .79341 & .629 \\
\hline Clean \& Tidy & 304 & 3.00 & 2.00 & 5.00 & 4.1974 & .82885 & .687 \\
\hline Staff Attitude & 304 & 3.00 & 2.00 & 5.00 & 4.2105 & .82559 & .682 \\
\hline Safe Place & 304 & 4.00 & 1.00 & 5.00 & 4.2434 & .83644 & .700 \\
\hline
\end{tabular}

\section{Inferential Statistics}

The gathered data was first screened and then tested for common method variance (CMV) by using SPSS statistical software to check common bias. After that, structural Equation Modelling (SEM) technique was utilized model measurements by using AMOS software. SEM was used in this study because of the complex nature of the model and assessing the proposed framework.

This section presents a detailed analysis of data and is divided into two sections. The "outer model" contains statistical testing to determine reliability and validity of instruments. While the "Inner Model" involves the analysis and interpretation of hypotheses testing along with predictive relevance of the model.

\subsection{Outer Model}

The outer measurement of the model was examined through Reliability testing and Confirmatory Factor analysis as described in the following section.

\subsubsection{Reliability Test}

Reliability testing determines the internal consistency of each item of the assigned variables (Hair, Hult, Ringle, \& Sarstedt, 2016). Reliability of measurement scales is evaluated from the Cronbach's Alpha. It can be seen that the values of these statistics are, in every case, above the required minimum values of 0.7 respectively (Nunally 1978; Hair et al. 1999), which supports inner reliability of the proposed constructs.

Table 3. Reliability scores for each variable

\begin{tabular}{ll}
\hline & Cronbach alpha \\
\hline Accessibility & .711 \\
\hline Atmosphere & .717 \\
\hline Environment & .620 \\
\hline Personnel & .631 \\
\hline
\end{tabular}


The alpha coefficient for accessibility is 0.711 , suggesting that the items lie in the acceptable range and have internal consistency. (Note that the value of coefficient is .70 or higher is considered "acceptable", or less than .07 is moderate, Coefficients that are less than 0.5 are usually unacceptable), in a same way store atmosphere has 0.717 (which is also acceptable), store environment has 0.620 (which is also acceptable), personnel 0.884 which is also acceptable.

Table 4. Reliability statistics

\begin{tabular}{lll}
\hline Cronbach's Alpha & Cronbach's Alpha Based on Standardized Items & N of Items \\
\hline .826 & .827 & 15 \\
\hline
\end{tabular}

Overall Cronbach's Alpha of the questionnaire was 0.826 . Which is significant as it is greater than the cut off value which is 0.7 . This depicts appropriate grounds to assert that internal consistencies in the data are quite significant and thus, the answers of the respondents display that the results would be reliable.

\subsubsection{Confirmatory Factor Analysis}

Confirmatory factor analysis was performed using AMOS. Factor analysis was employed to reduce large number of variables to extract most underlying variables called factor. Confirmatory factor analysis is a useful method to examine the variability among observed variables and excerpt variability from items and load them into a common factor. The researcher uses knowledge of the theory, empirical research, or both, postulates the relationship pattern a priority and then tests the hypothesis statistically. Diana D (2001).

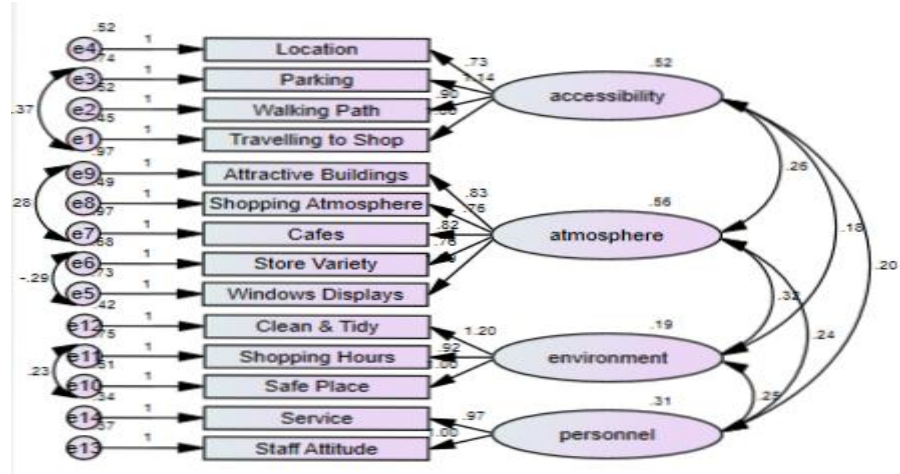

The measurement model of the latent constructs was also analyzed by confirmatory factor analysis (CFA; Table 5). The table shows Standardized factor loading for each item and shows the association between individual items with the extract construct. Factor loading for each item depicts reasonable to strong relationship with the underlying construct.

Table 5. Standardized regression weights

\begin{tabular}{llll}
\hline $\begin{array}{l}\text { Latent } \\
\text { Variable }\end{array}$ & Item Label & Item Description & $\begin{array}{l}\text { Standardized } \\
\text { Factor Weights }\end{array}$ \\
\hline Accessibility & $\begin{array}{l}\text { Location } \\
\text { convenience }\end{array}$ & The location of stores is convenient & .733 \\
\hline & Adequate parking & There is adequate parking & .670 \\
\hline & Pedestrianized area & $\begin{array}{l}\text { Pedestrianized areas make it easy to get to .691 } \\
\text { move around. }\end{array}$ & Travelling to shop here is easy and .591 \\
\hline
\end{tabular}




\begin{tabular}{|c|c|c|c|}
\hline & & straightforward. & \\
\hline \multirow[t]{5}{*}{ Atmosphere } & $\begin{array}{l}\text { Building } \\
\text { attractiveness }\end{array}$ & The building in this place look attractive. & .659 \\
\hline & Shopping atmosphere & $\begin{array}{l}\text { The overall atmosphere makes shopping } \\
\text { enjoyable. }\end{array}$ & .566 \\
\hline & Cafés and restaurants & $\begin{array}{l}\text { There is a good selection of cafes and } \\
\text { restaurants. }\end{array}$ & .529 \\
\hline & Store's variety & There is an excellent variety of stores. & .627 \\
\hline & Window displays & The window display is attractive. & .535 \\
\hline \multirow[t]{3}{*}{ Environment } & $\begin{array}{l}\text { Cleanliness } \\
\text { tidiness }\end{array}$ & The shopping are looks clean and tidy & .515 \\
\hline & Shopping hours & Shopping hours are convenient. & .417 \\
\hline & Safety & It feels like a safe place to shop. & .625 \\
\hline \multirow[t]{2}{*}{ Personnel } & Services & The service in the shop is good. & .677 \\
\hline & Staff attitudes & $\begin{array}{l}\text { The attitude of staff in the shops is helpful } \\
\text { and friendly. }\end{array}$ & .682 \\
\hline
\end{tabular}

\subsubsection{Evaluating Measurement Fitness Model}

To evaluate the fitness of the proposed model, Amos delivers a set of useful indices that are used to determine the fitness and validity of the hypothesized model. Out of different significant indices, root mean square error of approximation (RMSEA), goodness of fit index (GFI), Chi-Square, CMIN/DF, adjusted goodness of fit index (AGFI), and comparative fit indices were observed to determine the authenticity of the research model. The discussed indices show the degree to which constructs are related to one another. Table 6 demonstrates the resultant values.

Table 6. Model fitness test

\begin{tabular}{lll}
\hline Model Fit & Resultant Value & Threshold \\
\hline CMIN/DF & $203.220(67)$ & $<3$ good $;<5$ Acceptable \\
\hline CFI & .889 & Closer to $1 ;$ good \\
\hline GFI & .913 & $>0.90$ \\
\hline AGFI & .864 & $>0.80$ \\
\hline RMR & .062 & $<0.06$ \\
\hline RMSEA & .082 & $<0.05$ \\
\hline PCLOSE & .000 & $>0.05$ \\
\hline
\end{tabular}

The measured value of CMIN/DF is very good while the P-value is also good and meet the threshold. However, the values of AGFI, CFI, GFI, RMR and RMSEA are good and lie in the range of acceptable values thus this shows that model is good fit for research inferences.

\subsubsection{Structural Equation Modelling}

Structural Equation Modelling (SEM) was used to examine the hypotheses. SEM combines both regression analysis and factor analysis. SEM consists of seven major stages, from developing the model, constructing path diagram causal relationship, building and modifying measurement model and finally model fit (Hair et al., 2006). A structural equation model consists of an observed variable (OV) and latent variable (LV). The relationships of observes and latent variables in SEM are shown using path diagram (Gefen 2003, Tong 2007) 
SEM integrates both path and factor analyses including multiple observed variables or indicators for every unobserved variable as in factor analysis and specific paths connecting the unobserved variables in path analysis (Tong 2007).

To test the study hypothesis, we have used the structural equation model (SEM). Moreover, to evaluate the indirect and direct effects of all the constructs the testing was done. The use of (SEM) structural equation model has been observed to be a foremost procedure that has been used below different regression models and methods (Barron \& Kenny, 1986). Moreover, the equation of regression in study targets at explaining each construct to assess the cause and effect relationship while all the factors in the causal model could demonstrate their cause and effect at exact time. Likewise, the idea of using this model ensures to apply technique of bootstrapping which has been viewed as reasonable for both small and large sample size and does not require any kind of indirect effect (Hayes, 2013).

Additionally, the concept of utilizing the structural equation model makes sure to apply the bootstrapping technique that has been preferred to be accurate for the sample sizes either large or small. It also does not need any such kind of indirect effects. If the AVE is more than 0.5 than the result is drawn that the loadings are good but less than 0.5 are termed as less effective for the study. In order to check the all direct and indirect effects, a technique has been implemented which is known as bootstrapping (Shrout \& Bolger, 2002). The method was indicted by Baron \& Kenny (1986) and is criticized by number of researchers but is used widely in the rage of studies (MacKinnon, 2008). Additionally, the $\mathrm{p}$ values in the table depicts about the acceptance and rejection level by seeing the null hypothesis that depends on the upper and lower bounds of the confidence intervals.

Structural equation modeling used to evaluate the structural relationship between exogenous and endogenous variables. The structural equation modeling includes factor analysis and multivariate analysis of the model. Firstly, we evaluate the model fitness and measure whether the paths showing the relationship between measured and latent variables are significant or not. The path diagram showed in Figure 1. Besides Table 8 shows the model fit results by analyzing model fit indices.

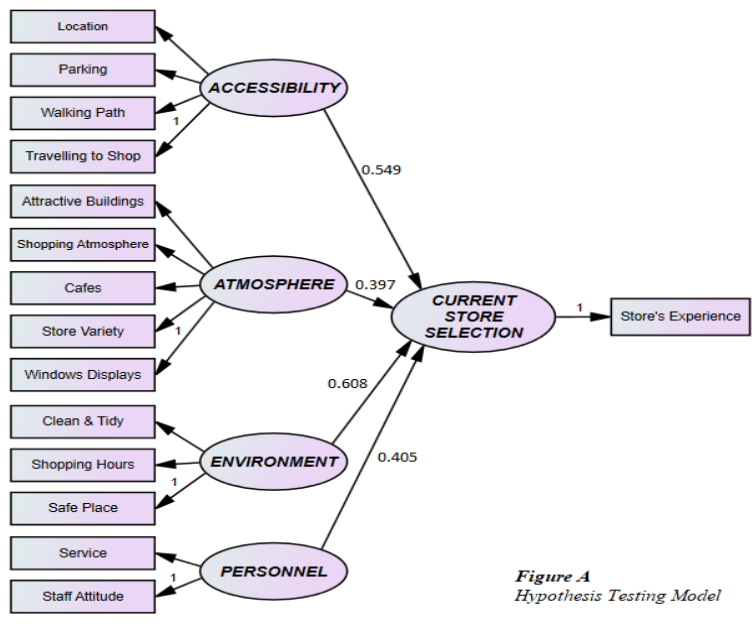

Figure 1. Hypothesis trsting model

\subsubsection{Evaluation Measurement Fitness Model}

Table 7. Model fit measures

\begin{tabular}{lllllll}
\hline Model & $\chi^{2}(\mathbf{d f})$ & $\mathbf{p}$ & RMSEA & NNFI & CFI & GFI \\
\hline Unrestricted & $199.842(75)$ & .000 & .074 & .849 & .898 & .919 \\
\hline
\end{tabular}

Note: RMSEA = root mean square error of approximation; NNFI = Non-Normed Fit Index; CFI = Comparative Fit Index; GFI = Goodness-of-Fit Index. 
A structural model fit was assessed and the fit statistics for this model are also shown in Table 1. More specifically, in the model, $\chi^{2}$ value which is significant at $p<.05$ (to be significant at the $5 \%$ level, the critical value for a Chi-Square change with one degree of freedom is 2.74). Similarly, we see that the Non-Normed Fit Index, the Comparative Fit Index, and the Goodness-of-Fit Index statistics of the model exceed or are very close to the recommended minimum value of 0.9 , while the RMSEA is located below the maximum limit of 0.08 (Hair et al. 1999).

\subsection{Inner Model}

After examining and establishing construct validity and reliability, the next step was to examine the proposed hypotheses using SEM (Structural Equation Modelling) technique using AMOS Software.

The observations are as follows; (Please refer to Figure A and Table 8)

a) First, 'Accessibility' has a significant impact on 'Current store selection (SSS)'

$(\beta=0.549, \mathrm{p}<.001)$, therefore H1a is supported.

b) Second, 'Atmosphere' also has a significant impact on 'Current store selection (SSS)' $(\beta=0.397, p<.001)$, therefore $\mathrm{H} 1 \mathrm{~b}$ is also supported.

c) Third, 'Environment' of the store also seems to have an impact on 'Current store selection (SSS)' $(\beta=0.608, \mathrm{p}$ $<.001)$, therefore $\mathrm{H} 1 \mathrm{~b}$ is also supported.

d) Fourth, 'Personnel' of the store are also influencing the 'Current store selection (SSS)' $(\beta=0.405, \mathrm{p}<.001)$, therefore $\mathrm{H} 1 \mathrm{~b}$ is also supported.

Table 8. Regression weights: (group number 1 - default model)

\begin{tabular}{|c|c|c|c|c|c|}
\hline & & & $\beta$ - coefficient & C.R. & $\mathbf{p}$ \\
\hline CURRENT_STORE & $<---$ & ACCESSIBILITY & .549 & 9.691 & $* * *$ \\
\hline $\begin{array}{l}\text { CURRENT_STORE } \\
\end{array}$ & <--- & ATMOSPHERE & .397 & 4.849 & $* * *$ \\
\hline $\begin{array}{l}\text { CURRENT_STORE } \\
\end{array}$ & <--- & ENVIRONMENT & .608 & 8.223 & $* * *$ \\
\hline $\begin{array}{l}\text { CURRENT_STORE } \\
\end{array}$ & <--- & PERSONNEL & .405 & 4.104 & $* * *$ \\
\hline Travelling to Shop & <--- & ACCESSIBILITY & 1.000 & & \\
\hline Walking path & $<---$ & ACCESSIBILITY & .814 & 7.890 & $* * *$ \\
\hline Parking & <--- & ACCESSIBILITY & .976 & 6.430 & $* * *$ \\
\hline Location & $<---$ & ACCESSIBILITY & .794 & 8.337 & $* * *$ \\
\hline Window displays & <--- & ATMOSPHERE & 1.000 & & \\
\hline Store Variety & $<---$ & ATMOSPHERE & .769 & 6.715 & $* * *$ \\
\hline Cafes & <--- & ATMOSPHERE & .829 & 7.400 & $* * *$ \\
\hline Shopping Atmosphere & $<---$ & ATMOSPHERE & .766 & 8.461 & $* * *$ \\
\hline Attractive buildings & <--- & ATMOSPHERE & .846 & 7.491 & $* * *$ \\
\hline Safe Place & $<---$ & ENVIRONMENT & 1.000 & & \\
\hline Shopping Hours & <--- & ENVIRONMENT & .921 & 8.166 & $* * *$ \\
\hline Clean \& Tidy & $<---$ & ENVIRONMENT & 1.190 & 8.776 & $* * *$ \\
\hline Staff Attitudes & <--- & PERSONNEL & 1.000 & & \\
\hline Service & $<---$ & PERSONNEL & .966 & 8.931 & $* * *$ \\
\hline Store's Experience & $<---$ & CURRENT_STORE & 1.000 & & \\
\hline
\end{tabular}




\section{Results and Discussions}

The primary hypothesis was that at a specific shopping centre the shopping experience is certainly related to selection of the shopping store by the customer. The hypothesis described that four dimensions i.e. 'atmosphere', 'accessibility', 'personnel service' and 'environment' collectively reflect the shopping experience. Structural Equation modelling (SEM) analysis using AMOS approves the existence of a four-dimensional reflection of the shopping experience concept as demonstrated by the fit indices mentioned in Table 7 being above the suggested statistical thresholds [Hu and Bentler, 1999].

It is observed that the analysis results show positive relationship between shopping experience and decision to select a specific store. For both females and males, this result is considerable offering support to 'H1'.

Shopping is a practical activity and choice of a shopping store is determined by people's shopping experience influencing them to be conclusive, and to have a pleasant exposure while completing their shopping quickly and efficiently. Clear managerial inferences are obtained from the results. From a theoretical viewpoint, the research narrates to the previous work regarding influences on shopping/convenience store selection.

This could lead to possible concerns for shopping centre management. Marketing management could be subject to guaranteeing that people have a pleasant shopping experience and targeted promotional and advertising activities should be directed towards them which could pay increased dividends in terms of repeated shopping store's selection. Believably due to the socialization characteristic of the activity, the approaches of women and men towards shopping are changing [Severiens and Ten Dam, 1998]. The gap of generation between young and mature shoppers could be challenging conventional shopping drives; 'Youngsters today are more familiarized to shopping and appear to gain more pleasure out of it' [Minahan and Beverland, 2005, p. 174].

\section{Conclusion}

A key managerial product is the understanding that customers who go through a pleasant shopping experience anticipate returning to that shopping zone in future. An indication is given by the results that from their evaluation of regional shopping events, the customers derive enjoyment. This result is comparable to that generated by Wakefield and Baker [2004] who figured that excitement has a constructive influence upon shopping store's selection. It gives a clear reasoning then that if a shopping centre ensures efficient, fast, convenient, pleasant and safe shopping, this would plea to shoppers and they would enjoy shopping in that area and their chances to return to that area in future are more likely.

The research also indicates the retail store executives of regional shopping centers that bodies like local managers and authorities should be there in order to ensure the presence of maximized shopping experience in regional shopping centres.

A valuable standard for the retail executives to accomplish the shopping experience is also provided by this research. Attention is required to make shopping centres easily reachable and appealing to the of customers. For instance, the mature shoppers rather favor to shop by product category than brand [Minahan and Beverland, 2005], therefore, regional store bosses could pursue to group their shopping stores with respect to categories in future; also giving clear signage, guidelines and customer information points [Laroche, Saad, Cleveland and Browne, 2004].

Along with this, as women cover a higher segment of the shopping population, there is a very strong need to endorse characteristics of the shopping centre to be uplifting and more appealing to increase the enjoyment of females in that shopping site, to retain the loyalty of these customers and increase the chances of revisiting the same store in future.

\subsection{Unobserved Areas From Previous Researches Covered}

The earlier researchers involved the basic elements of the shopping experience and not the detailed aspects of the shopping experience for instance, it could be claimed that shopping enjoyment may influence the optional amount that shoppers are equipped to spend in a shopping trip; it is recognized from this research that the increased time spent in a retail store results in greater spending by the shopper. This research broadens the measuring scopes of the shopping experience influence.

The previous researches were all based on the intentions of the customers store selections but not on the actual shopping store selection decisions that they take [Cathy Hart and Andrew M. Farrell, 2010]. This research focuses more on the actual behaviors of the shoppers that they show while shopping at a destination and also if they actually visit back a specific shopping centre again or not.

Previous researches were carried out in the western regions of the globe such as the works performed by [Cathy Hart and Andrew M. Farrell, 2010; Wakefield and Baker, 1998]; but this research focuses on the eastern regions, 
particularly Pakistan, Asia. It is interesting to see how the concept of shopping entertainment relates to enjoyment, excitement and value perceptions of shoppers and how in return it affects a customer to revisit the store.

Earlier researches performed by Cathy Hart and Andrew M. Farrell have shown that store image has a significant role to play in consumer's store revisiting decisions, therefore, it could be assumed that the store image also has a significant impact on the decision-making process of the consumer. Although substantial efforts have been made on the part of store and also shopping centre image on customer's patronage, until now a very insignificant research had been made investigating the image of the regional shopping centre, as a comprehensive entity in defining customer's patronage decisions.

The majority research in this field has focused on responses of shoppers at an individual store or at shopping mall level but this study emphasis on a relatively unassessed area of research, in terms of discovering the comprehensive image of a shopping center and the impact it has upon shopper's future revisiting decision-making process. Additionally, the literature also indicates that shopping experience might be a function of gender. For example, discriminate gender discrepancies in shopping behavior, as a social activity the attitudes towards shopping and involvement in the shopping process. This is evident with the view that women behave very differently as compared to men and often show contradictory approaches to socialization.

\subsection{Limitations and Future Research}

The specific areas used by customers to evaluate their enjoyment of shopping activity in a particular shopping store are indicated by the nature of scale in this paper. However, it is legit to consider the limitations of work while conducting any research.

1. At first, this work is cross-sectional that measures the enjoyment of respondent's shopping experience and aims to choose a shopping centre at a specific time. Therefore, deductions related to fundamental order among the variables of interest could not be generated, and while interpreting the conclusions, certain care should be taken into consideration.

2. Second, even though this research has defined many variables that are related to shopping experience enjoyment, it is still possible that these variables could be more influential than others when it comes to enjoyment levels and repatronage intentions. Future research could be conducted to investigate the factors used by customers to evaluate their shopping enjoyment and a specific regional store. Moreover, it would also be effective to identify and investigate other consumer segments such as shopper's age, education, income, etc.

3. Third, only some limited variables were measured in this research. There could be other factors that may be considered in the domain of shopping experience. The quantity and quality of the enjoyment offered in a shopping destination could be one of the possibilities. For instance, some of the shopping destinations offer added entertainment during special seasons such as EID, Ramadan, Independence Day, etc. Therefore, enjoyment of shopping activity could also be affected by seasonal occasions.

4. It could also be observed that shopping experience enjoyment may affect more than just intentions of visiting a shopping location again in future. Such as, the average amount that a shopper spends in a shopping activity could also be affected by shopping enjoyment, therefore, it wouldn't be wrong to say that higher spending is a result of increased time spent in a shopping store [Donovan, Rossiter, Marcoolyn and Nesdale. 1994; Wakefield and Baker, 1998]. Thus, shopping enjoyment is expected to increase the time spent by a shopper in a store and also the willingness to spend more money.

Finally, as the research was conducted only in specific regions of Pakistan, therefore, to investigate the outcomes of the results both nationally and across the borders would be interesting. Across the different geographical regions of the globe, the dimensions of customer's enjoyment could be altered when it comes to shopping experience. This aspect has triggered many researchers towards the consumer behavior segment internationally and various works are in progress. However, by taking all these limitations into consideration, it is clear that a significant contribution could be made to the retail market consumer behavior literature by this study and also a number of areas that potentially need attention are identified for future research.

\section{References}

Allegra. (2002). Shopping Centres in the UK. London: Allegra Strategies.

Arnold, M. J., \& Reynolds, K. E. (2003). Hedonic shopping motivations. Journal of Retailing, 108(2), 1-20. https://doi.org/10.1016/S0022-4359(03)00007-1

Babin, B. J., \& Darden, W. R. (1996). Good and bad shopping vibes: Spending and patronage satisfaction. Journal of 
Business Research, 35(3), 201-206. https://doi.org/10.1016/0148-2963(95)00125-5

Babin, L. A., Babin, B. J., \& Boles, J. S. (1999). The effects of consumer perceptions of the sales person, product and dealer on purchase intentions. Journal of Retailing and Consumer Services. https://doi.org/10.1016/S0969-6989(98)00004-6

Baker, J., Parasuraman, A., Grewal, D., \& Voss, G. B. (2002). The influence of multiple store environment cues on perceived merchandise value and patronage intentions. Journal of Marketing. https://doi.org/10.1509/jmkg.66.2.120.18470

Bakewell, C., \& Mitchell, V.-W. (2004). Male Consumer Decision-Making Styles. International Review of Retail, Distribution and Consumer Research. https://doi.org/10.1080/0959396042000178205

Bell, S. (1999). Image and Consumer Attraction to Intraurban Retail Areas: An Environmental Psychology Approach. Journal of Retailing and Consumer Services. https://doi.org/10.1016/S0969-6989(98)00015-0

Burns, D. J., \& Warren, H. B. (1995). Need for uniqueness: shopping mall preference and choice activity. International Journal of Retail and Distribution Management. https://doi.org/10.1108/09590559510103954

Campbell, C. (1997). Shopping, Pleasure and the Sex War. In P. Falk, \& C. Campbell (Eds.), The Shopping Experience. London: Sage. https://doi.org/10.4135/9781446216972.n8

Chavosh, A., Halimi, A. B., \& Namdar, J. (2011). The contribution of product and consumer characteristics to consumer's impulse purchasing behaviour in Singapore. Proceedings of International Conference on Social Science and Humanity, 5, 248-252.

Churchill, G. A., \& Iacobucci, D. (2004). Marketing Research: Methodological Foundations. Chicago, IL: Dryden Press.

Dabholkar, P. A., Thorpe, D. I., \& Rentz, J. O. (1996). A Measure of Service Quality for Retail Stores: Scale Development and Validation, Journal of the Academy of Marketing Science. https://doi.org/10.1007/BF02893933

Darden, W. R., \& Babin, B. J. (1994). Exploring the concept of affective quality: expanding the concept of retail personality. Journal of Business Research. https://doi.org/10.1016/0148-2963(94)90014-0

Darian, J. C., Tucci, L.A., \& Wiman, A. R. (2001). Perceived salesperson service attributes and retail patronage intentions. International Journal of Retail and Distribution Management. https://doi.org/10.1108/09590550110390986

Dennis, C., Newman, A., \& Marsland, D. (2005). Objects of Desire: Consumer Behaviour in Shopping Centre Choices. Basingstoke: Palgrave MacMillan. https://doi.org/10.1057/9780230509481

Dholakia, R. R. (1999). Going shopping: key determinants of shopping behaviours and motivations. International Journal of Retail and Distribution Management. https://doi.org/10.1108/09590559910268499

Finn, A., \& Louviere, J. J. (1996). Shopping Center Image, Consideration, and Choice: Anchor Store Contribution. Journal of Business Research. https://doi.org/10.1016/0148-2963(95)00129-8

Fischer, E., \& Arnold, S. J. (1994). Sex, Gender Identity, Gender Role Attitudes, and Consumer Behavior. Psychology \& Marketing. https://doi.org/10.1002/mar.4220110206

Gerbing, D. W.. \& Hamilton, J. G. (1996). Viability of Exploratory Factor Analysis as a Precursor to Confirmatory Factor Analysis. Structural Equation Modeling. https://doi.org/10.1080/10705519609540030

Grewal, D., Baker, J., Levy, M., \& Voss, G. B. (2003). The effects of wait expectations and store atmosphere evaluations on patronage intentions in service-intensive retail stores. Journal of Retailing. https://doi.org/10.1016/j.jretai.2003.09.006

Hart, C., \& Farrell, A. M. (2010). Shopping Experience Enjoyment: Impact on Customers' Repatronage Intentions and Gender Influence. The Shopping Experience. London: Sage.

Haytko, D. L., \& Baker, J. (2004). It's all at the mall: exploring adolescent girls' experiences. Journal of Retailing. https://doi.org/10.1016/j.jretai.2004.01.005

Holbrook, M. B., \& Hirschman, E. C. (1982). The experiential aspects of consumption: Consumer fantasies, feelings and fun. Journal of Consumer Research, 9(2), 132-140. https://doi.org/10.1086/208906

Hu, L.-T., \& Bentler, P. M. (1999). Cutoff Criteria for Fit Indices in Covariance Structure Analysis: Conventional 
Criteria Versus New Alternatives. Structural Equation Modeling: A Multidisciplinary Journal. https://doi.org/10.1080/10705519909540118

Jin, B., \& Sternquist, B. (2004). Shopping is Truly a Joy. The Service Industries Journal. https://doi.org/10.1080/0264206042000299158

Kirkup, M. H., \& Rafiq, M. (1999). Marketing Shopping Centres: Challenges in the UK Context. Journal of Marketing Practice: Applied Marketing Science. https://doi.org/10.1108/EUM0000000004570

Kupke, V. (2004). Identifying the Dimensions to Retail Centre Image. Journal of Property Investment and Finance. https://doi.org/10.1108/14635780410550858

Laroche, M., Saad, G., Cleveland, M., \& Browne, E. (2000). Gender differences in information search strategies for a Christmas gift. Journal of Consumer Marketing. https://doi.org/10.1108/07363760010349920

Leo, P.-Y., \& Philippe, J. (2002). Retail Centres: Location and Customer Satisfaction. Service Industries Journal. https://doi.org/10.1080/714005055

Luomala, H. T. (2003). Understanding how retail environments are perceived: a conceptualization and a pilot study. International Review of Retail, Distribution and Consumer Research. https://doi.org/10.1080/0959396032000101381

Machleit, K. A., Meyer, T., \& Eroglu, S. A. (2005). Evaluating the Nature of Hassles and Uplifts in the Retail Shopping Context. Journal of Business Research. https://doi.org/10.1016/j.jbusres.2003.09.006

McGoldrick, P. (2002). Retail Marketing. McGraw Hill Education, Berkshire.

Minahan, S., \& Beverland, M. (2005). Why Women Shop. Milton, Qld: Wrightbooks.

Miranda M. J., Konya, L., \& Havrila, I. (2005). Shoppers' satisfaction levels are not the only key to store loyalty. Marketing Intelligence and Planning. https://doi.org/10.1108/02634500510589958

Oppewal, H., \& Timmermans, H. (1999). Modeling Consumer Perception of Public Space in Shopping Centers. Environment and Behavior. https://doi.org/10.1177/00139169921971994

Otnes, C., \& McGrath, M. A. (2001). Perceptions and Realities of Male Shopping Behavior. Journal of Retailing. https://doi.org/10.1016/S0022-4359(00)00047-6

Pandey, S. K. (2016). The effect of deals and moods on compulsive buying: A study on young Indian consumers. Global Business Review, 17(2), 1-12. https://doi.org/10.1177/0972150915619821

Phillips, M., \& Swaffin-Smith, C. (2004). Market Towns - Victims of Market Forces?. International Journal of Retail and Distribution Management. https://doi.org/10.1108/09590550410564782

Pine, B. J., \& Gilmore, J. (1998). Welcome to the experience economy. Harvard Business Review, 78(1), 97-105.

Rook, D. W. (1987). The buying impulse. Journal of Consumer Research, 14(2), 189-199. https://doi.org/10.1086/209105

Severiens, S., \& Ten Dam, G. (1998). Gender and Learning: Comparing Two Theories. Higher Education.

Sit J., Merrilees, B., \& Birch, D. (2003). Entertainment-Seeking Shopping Centre Patrons: The Missing Segments. International Journal of Retail and Distribution Management. https://doi.org/10.1108/09590550310461985

Sivadas, E., \& Baker-Prewitt, J. L. (2000). An examination of the relationship between service quality, customer satisfaction and store loyalty. International Journal of Retail and Distribution Management.

Stern, B. B. (1999). Gender and Multicultural Issues in Advertising: Stages on the Research Highway. Journal of Advertising. https://doi.org/10.1080/00913367.1999.10673572

Wakefield, K. L., \& Baker, J. (1998). Excitement at the Mall: Determinants and Effects on Shopping Response. Journal of Retailing. https://doi.org/10.1016/S0022-4359(99)80106-7

Wakefield, K. L., \& Baker, J. (1998). Excitement at the mall: Determinants and effects on shopping response. Journal of Retailing, 74(3), 515-540. https://doi.org/10.1016/S0022-4359(99)80106-7

Whyatt, G. (2004). Town Centre Management: how theory informs a strategic approach. International Journal of Retail and Distribution Management. https://doi.org/10.1108/09590550410541462

Williams, P., Hubbard, P., Clark, D., \& Berkeley, N. (2001). Consumption, exclusion and emotion: the social geographies of shopping. Social and Cultural Geography. https://doi.org/10.1080/14649360122365 